\title{
Genetic diversity of local sorghum (Sorghum bicolor) genotypes of East Java, Indonesia for agro-morphological and physiological traits
}

\author{
SULISTYAWATI ${ }^{1, \boldsymbol{}}$, DYAH ROESWITAWATI ${ }^{2}$, JABAL TARIK IBRAHIM ${ }^{3}$, MAFTUCHAH $^{2}$ \\ ${ }^{1}$ Faculty of Agriculture, Universitas Merdeka Pasuruan. Jl. Ir. H. Juanda No. 68, Pasuruan City 67129, East Java, Indonesia \\ Tel.: +62-343-413619, Fax.: +62-343-420926, ‘email: mommyandri@gmail.com \\ ${ }^{2}$ Department of Agrotechnology, Faculty of Agriculture and Animal Science, Universitas Muhammadiyah Malang. Jl. Raya Tlogomas 246, Malang City \\ 65144, East Java, Indonesia \\ ${ }^{3}$ Department of Agribusiness, Faculty of Agriculture and Animal Science, Universitas Muhammadiyah Malang. Jl. Raya Tlogomas 246, Malang City \\ 65144, East Java, Indonesia
}

Manuscript received: 20 May 2019. Revision accepted: 15 August 2019.

\begin{abstract}
Sulistyawati, Roeswitawati D, Ibrahim JT, Maftuchah. 2019. Genetic diversity of local sorghum (Sorghum bicolor) genotypes of East Java, Indonesia for agro-morphological and physiological traits. Biodiversitas 20: 2503-2510. Sorghum (Sorghum bicolor (L.) Moench) has great potential to be cultivated because it has extensive adaptability, tolerant to drought and puddles, can produce on marginal land and relatively resistant to pests and diseases. To meet the food requirement, sorghum can be grown in Indonesia as an alternative food source other than rice. This study aims to obtain information on the agro-morphological and physiological characters of nine local sorghum genotypes in East Java, Indonesia so that they can be used as parents in improving the nature of varieties. The experiment was conducted in a Randomized Block Design, using nine local sorghum genotypes from East Java in three replications. The nine local sorghum genotypes are Sb.Pas, Sb.Lmg 1, Sb.Lmg 2, Sb.Tbn, Sb.Spg 1, Sb.Spg 2, Sb.Tag 1, Sb.Tag 2 and Sb.Jbg. The result showed that nine genotypes that are characterized have a variety of morphological (quantitative and qualitative), agronomic and physiological characters. According to the whole characters observed, there are five genotypes that are recommended for breeding programs, namely Sb.Lmg 1, Sb.Tbn, Sb.Spg 2, Sb.Tag1 and sb.Tag2. This can be proved by the morphological character, genotype Sb.Lmg 1, Sb.Tbn, Sb.Spg 2, Sb.Tag 1 and Sb.Tag2 have a high value of Agronomy character, genotype Sb.Tbn, Sb.Tag 1 and Sb.Tag 2 noted highest production acres- ${ }^{1}$ harvest age of genjah and medium; the Physiology character, high protein and carbohydrate substances reached by the Sb.Lmg 1 genotype, Sb.Tbn and Sb.Spg 2.
\end{abstract}

Keywords: Genetic variation, local genotypes, sorghum, Sorghum bicolor

\section{INTRODUCTION}

In order to meet the needs of growing population of Indonesia, food production needed to be increased. The limited land that is suitable for crop production and global climate change that is difficult to predict is one of the obstacles that must be faced (Luna and Widowati 2014). Marginal land area in Indonesia noted about 38.7 million acres but only about $58.4 \%$ which utilized (Susilowati and Saliem 2013), thus, there are considerable opportunities for increasing the production and obtain the superior sorghum varieties (Subagio and Aqil 2014).

The development of sorghum in Indonesia has not been optimized yet, the latest data proved to be extensive acreage, production and the needs of sorghum has yet to available (Zubair 2016). The vast acreage of growing sorghum in 2012 according to the Directorate General of Food Crops around 7,695 ha (Subagio and Suryawati 2013), whereas, the data from Directorate of Cultivation Grain in 2013 showed that sorghum production in Indonesia at the last 5 years only increase from 6,114 tons to 7,695 tons (Subagio and Aqil 2014).

Sorghum is a multipurpose crop, both as food, feed, and processed industrial materials (Kimber et al. 2013). Besides as a substitute of rice, sorghum flour can also be substituted flour in making bread and cakes. As a livestock feed, sorghum seed used as mixed materials to feed poultry rations, while the stem and leaves are widely used for ruminant livestock. Sorghum seeds had the potential to be used as industrial raw materials of beer, starch, syrup, and ethanol (Luna and Widowati 2014).

As a food ingredient, sorghum nutrition is not much different from other cereals (ICRISAT 2004). In general, protein levels of sorghum are higher than corn, brown rice, and millet but lower than wheat. The fat content of sorghum is higher than brown rice, wheat, millet but lower than corn (Mejia and Lewis 1999). The nutritional content of sorghum compared to other cereals is presented in Table 1 .

There is less sorghum crop improvement work in Indonesia. In East Java, there are still wild sorghum genotypes that have not been identified and characterized (Susilowati and Saliem 2013). These plants are found in several areas, including Lamongan, Bojonegoro, Tuban, and Probolinggo (Talanca and Andayani 2013). Identification of wild genotypes and existing accessions needs to be done in order to develop local sorghum cultivars. Identification and characterization are the first steps used to find plant genetic variation in the development of a type of superior cultivar through breeding. Without diversity, improvement in the nature of a plant is not possible (Mofokeng et al. 2012). 
Table 1. Nutrient composition of sorghum and other cereals (per $100 \mathrm{~g})$

\begin{tabular}{lcccccc}
\hline \multirow{2}{*}{ Commodity } & $\begin{array}{c}\text { Ash Fat } \\
\text { (g) }\end{array}$ & $\begin{array}{c}\text { (g) } \\
\text { Protein }\end{array}$ & $\begin{array}{c}\text { Carbo- } \\
\text { hydrate }(\mathbf{g})\end{array}$ & $\begin{array}{c}\text { Crude } \\
\text { fiber }(\mathrm{g})\end{array}$ & $\begin{array}{c}\text { Energy } \\
(\mathbf{k c a l})\end{array}$ \\
\hline Sorghum & 1.6 & 3.1 & 10.4 & 70.7 & 2.0 & 329.0 \\
Brown rice & 1.3 & 2.7 & 7.9 & 76.0 & 1.0 & 362.0 \\
Corn & 1.2 & 4.6 & 9.2 & 73.0 & 2.8 & 358.0 \\
Wheat & 1.6 & 2.0 & 11.6 & 71.0 & 2.0 & 342.0 \\
Millet & 2.6 & 1.5 & 7.7 & 72.6 & 3.6 & 336.0 \\
\hline
\end{tabular}

Source: Directorate of Nutrition, Indonesian Ministry of Health (1992)

The Food Security Agency includes sorghum as one of the supporting commodities for national food diversification. Research results from the Cereals Research Institute showed that sorghum can substitute rice up to $30 \%$ with tastes that can be accepted by consumers (Suarni and Firmansyah 2013). In a food self-sufficiency program, the Agricultural Research and Development Agency has made efforts to procure new improved varieties of sorghum, but because the development priorities are still in the rice and corn commodities, 15 varieties have been released from 1960 to 2001, 6 in 2013-2016 (Talanca and Andayani, 2013; Center for Research and Development of Food Crops 2013-2016).

This fact must be immediately addressed, among other by exploring and collecting of local sorghum genotypes as the first step in efforts to preserve and develop genetic resources and increase the genetic quality of varieties through plant breeding programs. East Java local sorghum genotypes is a plant that has been existed and cultivated hereditary by farmers in the region of East Java (Pasuruan, Lamongan, Tuban, Sampang, Tulungagung and Jombang) and has not been identified yet. This is important to do because the sorghum varieties and local genotypes are being pushed up by other food commodities. Besides that, in breeding programs, the more germplasm collections that are owned, the greater the chance to obtain superior gene sources that will be assembled into superior varieties (Sumarno and Zuraida 2004).

Based on the development of sorghum superior variety data in Indonesia and the fact that government efforts are still needed to support the success of food security, it is necessary to conduct research on the study of several local sorghum genotypes in East Java in order to obtain information on the diversity of each genotype. The result of local sorghum germplasm collection will be useful as parents in breeding programs.

\section{MATERIALS AND METHODS}

\section{Study sites}

The study was conducted in October 2017 to January 2018 in Pasuruan City, East Java, Indonesia which is located at an altitude of $5 \mathrm{~m}$ above sea level, the average temperature is $29-34^{\circ} \mathrm{C}$, rainfall averages of $1430 \mathrm{~mm}$ year ${ }^{-1}$ (climatic conditions were obtained from the statistical center of the Pasuruan city 2017. Planting is done in paddy fields with alluvial soil types.

\section{Materials}

The tools used to conduct this study were farming tools and measuring instruments. The materials used were the seeds of nine local sorghum genotypes obtained from six districts in East Java, manure and NPK fertilizer (Urea, SP36 , and $\mathrm{KCl}$ ), pesticides and fungicides. District and genotype names are presented in Table 2. Performance of all genotypes is presented in Figure 1.

\section{Design and culture practice}

This study was laid in a Randomized Block Design with three replications and used nine local genotypes of sorghum. Each unit (plot) has 21 plants with 5 sample plants. All genotypes are planted simultaneously. Planting is done apart with space of $75 \times 15 \mathrm{~cm}$ on the trial plots. Treatment includes watering, weeding, piling, controlling pest and disease, and fertilizing.

\section{Observation}

Observations were taken on agro-morphological and physiological characters. Morphological characters include quantitative characters (plant height, number of leaves, stem diameter, panicle length, number of grains panicle- ${ }^{1}$, grain weight panicle- ${ }^{1}$, weight of 100 grains) (IBPGR/ICRISAT 1993) and qualitative characters (young leaf color, old leaf color, leaf bone color, density and shape of panicle, grain covering/glume length, glume color and grain color) (Munsell 2012; IBPGR/ICRISAT 1993; UPOV 2015). Agronomic characters include a number of tillers, grain production, flowering age, flowering to harvest age and harvest age. Physiological characters include moisture, ash, crude fiber, protein, crude fat, and carbohydrates (Salisbury and Cleon 1986).

\section{Data analysis}

Data analysis using Analysis of Variance with Minitab Software Version 17. Whether there is a difference between genotypes using Tukey Test of 5\%

Table 2. District and name of nine local sorghum genotypes from East Java, Indonesia

\begin{tabular}{lcl}
\hline District & $\begin{array}{c}\text { The number of } \\
\text { genotypes found }\end{array}$ & Naming genotype \\
\hline Pasuruan & 1 & Sb.Pas \\
Lamongan & 2 & Sb.Lmg 1 Sb.Lmg 2 \\
Tuban & 1 & Sb.Tbn \\
Sampang & 2 & Sb.Spg 1 Sb.Spg 2 \\
Tulungagung & 2 & Sb.Tag 1 Sb.Tag 2 \\
Jombang & 1 & Sb.Jbg \\
\hline
\end{tabular}




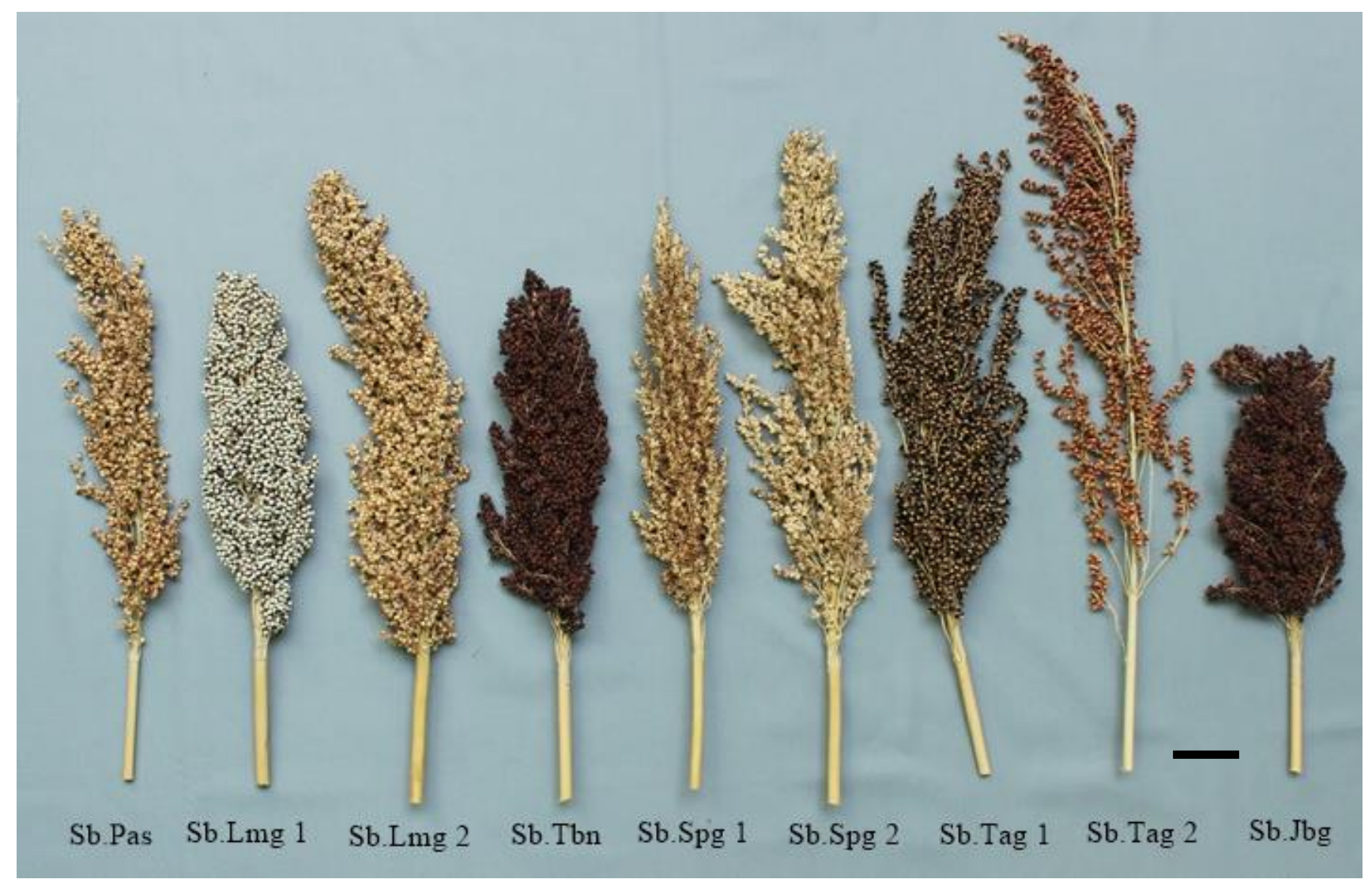

Figure 1. Performance of panicles nine local sorghum genotypes from East Java, Indonesia. Scale bar $=5 \mathrm{~cm}$

\section{RESULTS AND DISCUSSION}

\section{Quantitative morphological characters}

Based on analysis of variance among genotypes for quantitative characters observed, namely plant height, number of leaves, stem diameter, panicle length, number of grains panicle $^{-1}$, grain weight panicle ${ }^{-1}$, the weight of 100 grain shows that the results are significantly different at the level of 5\%. According to Elvira et al. (2015), differences in plant growth and production are influenced by internal factors such as genes and hormones that influence growth through inherited traits. External factors such as nutrients, water, temperature, humidity, and light also have different influences on the characteristics of a plant.

\section{Plant height, number of leaves and stem diameter}

Based on the results of the Tukey Test, several genotypes showed differences in plant height, a number of leaves and stem diameter. In Table 3, the plant height of the Sb.Tag 1 genotype is higher than the others, which is $331.81 \mathrm{~cm}$. The shortest genotype was Sb.Lmg 1 (153.79 $\mathrm{cm})$ and not different from Sb.Spg 2 genotype. The highest number of leaves was also found in the Sb.Tag 1 genotype, which was 10.93 strands although not different from the Sb.Lmg 1 genotype while the minimum number of leaves were in the Sb.Spg 1 genotype (6.07 strands) and there are several matching genotypes. Stem diameter does not much diverse, some genotypes show similarities and the range of stem diameter was varied from $2.13 \mathrm{~cm}$ in Sb.Lmg 2 to $1.26 \mathrm{~cm}$ in Sb.Tag 2 genotype.

In general, the genotype $\mathrm{Sb}$. Lmg 1 has the best vegetative characters, indicated by the figure of the plant that is low, great quantities of leaves and larger diameter of stem. A low plant with large diameter makes the plant sturdy and not easily fall in addition to facilitate harvesting. The number of leaves that are widely expected to support the process of photosynthesis.

From the data above, it can be explained that tallest plants not always have many leaves because the sorghum stem consists of segments which are leaf seats. Plant height is influenced by the length of the segment while the number of leaves depends on the number of segments (Balakrishna and Bhat 2015).

The plant height, number of leaves and stem diameter in addition to the genetic characteristics of each genotype are also influenced by environmental factors and photosynthesis in leaves. This result is in line with the result of the Lampley et al. (2014) that differences in plant height, stem diameter, and a number of leaves of some sorghum varieties are influenced by genetic and environmental factors. 
Table 3. Plant height, number of leaves and stem diameter nine local sorghum genotypes from East Java, Indonesia

\begin{tabular}{|c|c|c|c|}
\hline Genotype & Plant height $(\mathrm{cm})$ & Number of leaves & Stem diameter $(\mathrm{cm})$ \\
\hline Sb.Pas & $213.94 \mathrm{~cd}$ & 7.93 & 1.36 \\
\hline Sb.Lmg 1 & 153.79 & 10.53 & 1.89 \\
\hline Sb.Lmg 2 & $193.10 \quad b c$ & 9.60 & 2.13 \\
\hline Sb.Tbn & 290.81 & 9.43 & 1.69 \\
\hline Sb.Spg 1 & 196.18 & 6.07 & 1.28 \\
\hline Sb.Spg 2 & 165.68 & 7.27 & 1.28 \\
\hline Sb.Tag 1 & 331.81 & 10.93 & 2.00 \\
\hline Sb.Tag 2 & 223.11 & 6.27 & 1.26 \\
\hline Sb.Jbg & 280.25 & 9.60 & 1.64 \\
\hline Tukey Test $5 \%$ & 27.81 & 1.24 & 0.77 \\
\hline
\end{tabular}

Note: The number followed by the same letters show no difference in the Tukey Test of 5\%

Table 4. Panicle length, number of grains panicle ${ }^{-1}$, grain weight panicle ${ }^{-1}$ and weight of 100 grains nine local sorghum genotypes from East Java, Indonesia

\begin{tabular}{|c|c|c|c|c|c|c|c|c|}
\hline \multirow{2}{*}{$\begin{array}{l}\text { Genotype } \\
\text { Sb.Pas }\end{array}$} & \multicolumn{2}{|c|}{$\begin{array}{c}\text { Panicle length } \\
(\mathrm{cm})\end{array}$} & \multicolumn{2}{|c|}{$\begin{array}{c}\text { Number of grain } \\
\text { panicle }^{-1}\end{array}$} & \multicolumn{2}{|c|}{$\begin{array}{c}\text { Grain weight panicle }^{-1} \\
\text { (g) }\end{array}$} & \multicolumn{2}{|c|}{$\begin{array}{c}\text { Weight of } 100 \text { grains } \\
\text { (g) }\end{array}$} \\
\hline & 32.59 & $\mathrm{~b}$ & 2149.53 & $\mathrm{bc}$ & 60.15 & $\mathrm{c}$ & 3.01 & bcd \\
\hline Sb.Lmg 1 & 26.20 & $\mathrm{a}$ & 3217.80 & $\mathrm{e}$ & 73.95 & de & 2.47 & $a b$ \\
\hline Sb.Lmg 2 & 39.00 & $\mathrm{c}$ & 3594.07 & $\mathrm{e}$ & 87.86 & $\mathrm{f}$ & 2.59 & $a b$ \\
\hline Sb.Tbn & 24.07 & $\mathrm{a}$ & 2661.33 & d & 89.84 & $\mathrm{f}$ & 2.65 & $a b c$ \\
\hline Sb.Spg 1 & 38.46 & $\mathrm{c}$ & 1217.47 & $\mathrm{a}$ & 33.90 & $\mathrm{a}$ & 2.32 & $\mathrm{a}$ \\
\hline Sb.Spg 2 & 42.39 & $\mathrm{~cd}$ & 2421.07 & $\mathrm{~cd}$ & 52.59 & $\mathrm{~b}$ & 2.65 & $a b c$ \\
\hline Sb.Tag 1 & 41.45 & $\mathrm{c}$ & 2736.07 & $\mathrm{~d}$ & 76.13 & $\mathrm{e}$ & 3.16 & $\mathrm{~cd}$ \\
\hline Sb.Tag 2 & 46.33 & $\mathrm{~d}$ & 1841.87 & $\mathrm{~b}$ & 55.03 & $\mathrm{~b}$ & 3.20 & $\mathrm{~d}$ \\
\hline Sb.Jbg & 22.22 & $\mathrm{a}$ & 2588.87 & $\mathrm{~d}$ & 72.13 & $\mathrm{~d}$ & 2.89 & bcd \\
\hline Tukey Test 5\% & 4.86 & & 421.77 & & 3.07 & & 0.55 & \\
\hline
\end{tabular}

Note: The number followed by the same letters show no difference in the Tukey Test of 5\%

Panicle length, number of grains panicle ${ }^{-1}$, grain weight panicle $^{-1}$ and weight of 100 grains

Based on observations, the diversity of genotypes can be recognized more clearly in the generative phase. There are differences in the morphology of the nine genotypes studied quantitatively and qualitatively. In Table 4, it can be seen that the Sb.Tag 2 genotype has the longest panicle $(46.33 \mathrm{~cm})$ and on par with Sb.Spg 2 genotype. The shortest panicle length is found in the Sb.Jbg genotype $(22.22 \mathrm{~cm})$ and was on par with Sb.Tbn and Sb.Lmg 1 genotypes. The more number of grain panicle ${ }^{-1}$ found Sb.Lmg 2 genotype, which is 3594.07 and not different from the Sb.Lmg 1 genotype, while the less number of grains were in the Sb.Spg 1 genotype, as many as 1217.47 . The Sb.Tbn genotype has the highest grain weight panicle1 , which is equal to $89.84 \mathrm{~g}$ and is not different from the Sb.Lmg 2 genotype. The Sb.Spg 1 genotype has a lower grain weight panicle ${ }^{-1}$ than the other genotypes, which is $33.9 \mathrm{~g}$. The highest weight of 100 grains was achieved by the Sb.Tag 2 genotype, amounting to $3.20 \mathrm{~g}$ even though some genotypes matched, while the lowest weight was found in the Sb.Spg 1 genotype was $2.32 \mathrm{~g}$ and there were several genotypes were on par with 100-grain weight.

In this generative stage, besides influenced by the environment, the role of leaves in producing dry matter during the photosynthesis process is crucial. In general, there is suitability between vegetative and generative growth of nine genotypes, it can be proved that the genotypes which have plant height, number of leaves and stems diameter high tend to produce panicle length, number of grains panicle ${ }^{-1}$, grain weight panicle ${ }^{-1}$ and weight of 100 grains high. The plant which produces length panicles is not always followed by the number and weight of seeds, it is related to the density of panicles. The number of seeds per panicle- ${ }^{1}$ on each of cultivars varies between 800 to 3,000 seeds (du Plesis, 2008). Gerik et al. (2003) explain that the grain size and weight depend on the ability of the plant, especially the leaves to produce dry matter during the grain filling process, $85 \%$ of the dry matter produced by leaves during the generative phase is directly distributed to the grains. Besides, weather, soil fertility and groundwater influence the size and weight of the grains. Aminon et al. (2015) showed a positive correlation between plant height and number of leaves with production, including panicle length and weight of 100 seeds.

\section{Qualitative morphological characters}

Qualitative morphological characters (young leaf color, old leaf color, leaf bone color, shape and density of panicle, grain covering/glume length, glume color, and grain color) in the nine observed genotypes showed diversity. This diversity is influenced by plant genetic factors and environmental factors. This result is in line with the result of Zubair (2016), contributors to the phenotypic variability 
(appearance) of an individual plant are genetic variation, environmental variations, and genetic and environmental interactions.

\section{Young leaf color, old leaf color, and leaf bone color}

The young leaf color is dominated by $5 \mathrm{GY} 6 / 6,5 \mathrm{GY}$ $6 / 8$ and $5 \mathrm{GY} 5 / 4$. The old leaf color is dominated by $5 \mathrm{GY}$ $5 / 4$ and $5 \mathrm{GY} 4 / 4$ colors while the leaf bone is dominated by 2.5 GY $8 / 6$ colors, 2.5 GY $8 / 8$ and 2.5 GY 8/4 (Table $5)$. This indicates that each genotype has a specific leaf character.

Each plant has a difference in expressing the genetic code it receives. The difference in color of young leaves, old leaves, and leaf bones is influenced by differences in the content of chlorophyll pigments. In higher plants, there are two kinds of chlorophyll, namely chlorophyll a which is dark green and chlorophyll $b$ which is light green. The ability of chlorophyll biosynthesis of each species and cultivar is also different (Salisbury and Cleon, 1986; Taiz, 2002; Hasidah, 2017).

\section{Shape and density of panicle, grain covering (glume length), glume color and grain color}

The results indicate that there are a variety shape and density of panicles, namely semi-loose drooping primary branches, loose drooping primary branches, very loose drooping primary branches, semi-compact elliptic and compact elliptic (IBPGR/ICRISAT, 1993). Based on UPOV (2015), there are three color groups of glume, namely medium yellow, black and reddish-brown, while the color of grains is more diverse, namely light brown, white, red-brown and yellowish-white. The grain covering by glume (glume length) also varies, namely very short, short, medium and long (Table 6).

The difference of sorghum genotype can be identified more clearly in the generative phase compared to vegetative phase. The nature of the panicle, husk, and seed can be used as a parameter to distinguish the characteristics of each genotype (Kusumawati et al. 2013). Panicle compactness, glume color, the presence of fur and grain color is the most qualitative properties varies between cultivars (Aminon et al. 2015). Sorghum panicle shaped solid or open. Seed is partially or completely covered by the husk. The seed color is red, white, yellow, brown; and the husk color is black, red or brown (du Plesis 2008).

\section{Agronomic character}

\section{Number of tillers and grain production}

Sorghum is plants that can form tillers. The number of tillers produced depends on soil fertility, groundwater, and other growing environments besides the influence of genetic factors. The number of tillers determines the amount of production because sorghum seedlings can produce grains but the number of tillers should be limited because it can affect the quantity and quality of the seeds of the main plant (House 1985; Andriani and Isnaini 2013). Gerik et al. (2003) stated that if environmental conditions grow favorably, sorghum can form tillers, both from the upper and lower stem segments. If the tillers are left unchecked, they produce a small number of extra grains but have lower quality and can delay harvesting for several weeks.

Table 5. Young leaf colors, old leaf colors and leaf bone colors nine local sorghum genotypes from East Java, Indonesia

\begin{tabular}{|c|c|c|c|}
\hline Genotype & Young leaf color*) & Old leaf color*) & Leaf bone color*) \\
\hline Sb.Pas & $26.67 \% 5$ GY $6 / 6+73.33 \% 5$ GY $5 / 4$ & $100 \% 5$ GY $5 / 4$ & $100 \% 2.5 \mathrm{GY} 8 / 6$ \\
\hline Sb.Lmg 1 & $66.67 \% 5$ GY $6 / 8+33.33 \% 5$ GY $5 / 4$ & $100 \% 5 \mathrm{GY} 4 / 4$ & $100 \% 2.5 \mathrm{GY} 8 / 4$ \\
\hline Sb.Lmg 2 & $26.67 \% 5$ GY $6 / 6+73.33 \% 5$ GY $5 / 4$ & $66.67 \% 5$ GY $4 / 6+33.33 \% 5$ GY $5 / 4$ & $100 \% 2.5$ GY $8 / 6$ \\
\hline Sb.Tbn & $26.67 \% 5$ GY $6 / 6+73.33 \% 5$ GY $5 / 4$ & $33.33 \% 5$ GY $4 / 4+66.67 \% 5$ GY $5 / 4$ & $53.33 \% 2.5$ GY $8 / 4+46.67 \% 2.5$ GY $8 / 6$ \\
\hline Sb.Spg 1 & $100 \% 5$ GY $5 / 4$ & $100 \% 5$ GY $5 / 4$ & $100 \% 2.5 \mathrm{GY} 8 / 8$ \\
\hline Sb.Spg 2 & $100 \% 5$ GY $6 / 8$ & $100 \% 5$ GY $5 / 6$ & $100 \% 2.5 \mathrm{GY} 8 / 8$ \\
\hline Sb.Tag 1 & $33.33 \% 5$ GY $5 / 4+66.67 \% 5$ GY $6 / 6$ & $100 \% 5$ GY $6 / 6$ & $100 \% 2.5 \mathrm{GY} 8 / 6$ \\
\hline Sb.Tag 2 & $33.33 \% 5$ GY $5 / 4+66.67 \% 5$ GY $6 / 6$ & $100 \% 5$ GY $4 / 4$ & $26.67 \% 2.5$ GY $8 / 8+73.33 \% 2.5$ GY $8 / 6$ \\
\hline Sb.Jbg & $33.33 \% 5$ GY $6 / 8+66.67 \% 5$ GY $6 / 6$ & $33.33 \% 5$ GY $4 / 4+66.67 \% 5$ GY $5 / 4$ & $100 \% 2.5 \mathrm{GY} 8 / 4$ \\
\hline
\end{tabular}

Note: ${ }^{*}$ Characterization based on Munsell Tissue Colour Book (Munsell 2012)

Table 6. Shape and density of panicles, grain covering (glume length), glume color and grain color nine local sorghum genotypes from East Java, Indonesia

\begin{tabular}{|c|c|c|c|c|}
\hline Genotype & $\begin{array}{c}\text { Shape and Density } \\
\text { of Panicles *) }\end{array}$ & $\begin{array}{l}\text { Grain Covering } \\
\left.\text { (Glume Length) }^{* *}\right)\end{array}$ & $\begin{array}{l}\text { Glume } \\
\left.\text { Color }^{* *}\right)\end{array}$ & $\begin{array}{c}\text { Grain } \\
\text { Color }\end{array}$ \\
\hline Sb.Pas & Loose drooping primary branches & Medium $(75 \%)$ & Medium yellow & Light brown \\
\hline Sb.Lmg 1 & Compact elliptic & Very short $(25 \%)$ & Black & White \\
\hline Sb.Lmg 2 & Loose drooping primary branches & Medium (75\%) & Medium yellow & Light brown \\
\hline Sb.Tbn & Semi-compact elliptic & Short $(50 \%)$ & Black & Red-brown \\
\hline Sb.Spg 1 & Semi-loose drooping primary branches & Medium $(75 \%)$ & Medium yellow & Light brown \\
\hline Sb.Spg 2 & Semi-loose drooping primary branches & Medium $(75 \%)$ & Medium yellow & Light brown \\
\hline Sb.Tag 2 & Very loose drooping primary branches & Long $(100 \%)$ & Reddish-brown & Yellowish white \\
\hline Sb.Jbg & Semi-compact elliptic & Short $(50 \%)$ & Black & Red-brown \\
\hline
\end{tabular}

Note: ${ }^{*)}$ Determination based on IBPG/ICRISAT (1993). ${ }^{* *}$ Determination based on UPOV (2015) 
As shown in Table 7, the number of tillers is not directly proportional to production because the amount of production is also influenced by panicle length, a number of grains panicle ${ }^{-1}$, grain weight panicle ${ }^{-1}$, and weight of 100 grains. This is consistent with the research of Yoseph and Sorsa (2014). The highest production was reached by the Sb.Tbn genotype and was not different from the Sb.Tag 2 and Sb.Tag 1 genotypes while the lowest production was found in the Spg 1 genotype.

\section{Flowering age, flowering to harvest age and harvest age}

The diversity of flowering age, flowering to harvest age and harvest age in nine genotypes studied, results show that each genotype has a different response to its growing environment (Table 8). Sorghum is a short-day plant, meaning that plants require short days (long nights) before proceeding to the stage of reproduction. A very optimal to induce the formation of flowers is 10 to 11 hours. The photoperiod is longer than 11 to 12 hours of stimulating the growth of vegetative (House 1985; du Plesis 2008).

According to Kumar et al. (2013), photoperiodicity is an important factor in determining the time of flowering and harvesting. Besides, genetic factors also play a role in determining the life cycle of plants. Each variety has a different critical photoperiod (Kumar 2016). Lampley et al. (2014) said that genotypes have a significant effect on the number of days up to $50 \%$ flowering and the number of days up to $95 \%$ of physiological maturity.

Based on the maturity there were two groups, namely early maturing genotypes (Sb.Pas, Sb.Lmg 1, Sb.Tag 1, Sb.Tag 2) and medium age genotypes (Sb.Lmg 2, Sb.Tbn, Sb.Spg 1, Sb.Spg 2 and Sb.Jbg ). This is in line with the study conducted by Tabri and Zubachtirodin (2013) that the age of sorghum harvest is classified into three, namely early maturity ( $<80$ days), medium age (80-100 days) deep age $>100$ days).
Table 7. Number of tillers and production nine local sorghum genotypes from East Java, Indonesia

\begin{tabular}{lclrl}
\hline Genotype & Number of tillers & $\begin{array}{c}\text { Grain production } \\
\text { (ton hectare }\end{array}$ \\
\hline Sb.Pas & 3.56 & $\mathrm{bcd}$ & 4.09 & $\mathrm{bc}$ \\
Sb.Lmg 1 & 2.56 & $\mathrm{ab}$ & 4.28 & $\mathrm{bc}$ \\
Sb.Lmg 2 & 3.22 & $\mathrm{abcd}$ & 4.44 & $\mathrm{bc}$ \\
Sb.Tbn & 2.67 & $\mathrm{ab}$ & 6.87 & $\mathrm{~d}$ \\
Sb.Spg 1 & 3.89 & $\mathrm{~cd}$ & 1.94 & $\mathrm{a}$ \\
Sb.Spg 2 & 2.33 & $\mathrm{a}$ & 3.83 & $\mathrm{~b}$ \\
Sb.Tag 1 & 4.11 & $\mathrm{~d}$ & 5.53 & $\mathrm{~cd}$ \\
Sb.Tag 2 & 5.33 & $\mathrm{e}$ & 6.15 & $\mathrm{~d}$ \\
Sb.Jbg & 2.89 & $\mathrm{abc}$ & 4.04 & $\mathrm{bc}$ \\
Tukey Test 5\% & 1.21 & 1.63 & \\
\hline
\end{tabular}

Note: The numbers followed by the same letters show no difference in the Tukey Test 5\%

Table 8. Flowering age, flowering to harvest age and harvest age nine local sorghum genotypes from East Java, Indonesia

\begin{tabular}{lcccl}
\hline Genotype $\begin{array}{c}\text { Flowering } \\
\text { age } \\
(\text { DAP)*) }\end{array}$ & $\begin{array}{c}\text { Flowering } \\
\text { to harvest } \\
\text { age (day) }\end{array}$ & $\begin{array}{c}\text { Harvest } \\
\text { age } \\
(\text { DAP)*) }\end{array}$ & $\begin{array}{c}\text { Age } \\
\text { classification**) }\end{array}$ \\
\hline Sb.Pas & 45 & 27 & 72 & Early maturity \\
Sb.Lmg 1 & 46 & 27 & 73 & Early maturity \\
Sb.Lmg 2 & 48 & 35 & 83 & Medium age \\
Sb.Tbn & 50 & 32 & 82 & Medium age \\
Sb.Spg 1 & 39 & 45 & 84 & Medium age \\
Sb.Spg 2 & 39 & 47 & 86 & Medium age \\
Sb.Tag 1 & 50 & 26 & 76 & Early maturity \\
Sb.Tag 2 & 37 & 32 & 69 & Early maturity \\
Sb.Jbg & 50 & 38 & 88 & Medium age \\
\hline Note: ${ }^{*)}$ DAP (Days After Planting). ${ }^{* *}$ Classification based on \\
Age classification of sorghum varieties (Tabri and Zubachtirodin \\
2013)
\end{tabular}

Table 9. Moisture content, ash, protein, crude fat, crude fiber, carbohydrates nine local sorghum genotypes from East Java, Indonesia

\begin{tabular}{lccccccc}
\hline \multicolumn{1}{c}{ Genotype } & $\begin{array}{c}\text { Dry weight } \\
(\boldsymbol{\%})\end{array}$ & $\begin{array}{c}\text { Moisture } \\
\text { content } \mathbf{( \% )}\end{array}$ & $\begin{array}{c}\text { Ash } \\
(\mathbf{\%})\end{array}$ & $\begin{array}{c}\text { Protein } \\
(\boldsymbol{\%})\end{array}$ & $\begin{array}{c}\text { Crude fat } \\
(\boldsymbol{\%})\end{array}$ & $\begin{array}{c}\text { Crude fiber } \\
(\boldsymbol{\%})\end{array}$ & Carbohydrate $(\boldsymbol{\%})$ \\
\hline Sb.Pas & 88.44 & 11.56 & 3.66 & 10.25 & 3.39 & 5.03 & 66.11 \\
Sb.Lmg 1 & 87.96 & 12.04 & 1.53 & 11.34 & 2.58 & 3.04 & 69.47 \\
Sb.Lmg 2 & 89.86 & 10.14 & 3.58 & 11.15 & 3.81 & 5.12 & 66.20 \\
Sb.Tbn & 90.43 & 9.57 & 3.25 & 10.60 & 4.33 & 3.47 & 68.78 \\
Sb.Spg 1 & 89.24 & 10.76 & 2.20 & 15.30 & 3.69 & 2.54 & 65.51 \\
Sb.Spg 2 & 88.01 & 11.99 & 4.09 & 13.13 & 3.24 & 6.28 & 61.27 \\
Sb.Tag 1 & 88.24 & 11.76 & 3.37 & 8.97 & 3.74 & 5.49 & 66.67 \\
Sb.Tag 2 & 88.27 & 11.73 & 3.59 & 10.48 & 3.52 & 7.14 & 63.54 \\
Sb.Jbg & 87.42 & 12.58 & 2.38 & 10.47 & 3.87 & 3.36 & 67.34 \\
Nutritional range & & & $1.00-2.00$ & $11.00-13.00$ & $2.00-5.00$ & $1.00-3.00$ & $70.00-80.00$ \\
(Andriani and Isnaini 2013) & & &
\end{tabular}

Note: Ash content based on AOAC 2005, protein-based on SNI-2891-1992 Item 7.1, crude fat based on SNI-2891-1992 Item 8.1, crude fiber based on SNI-2891-1992 Item 11. 


\section{Physiological characters: Moisture content, ash, protein, crude fat, crude fiber, carbohydrates}

Nutrients contained in sorghum seeds are determined by nutrients absorbed by roots and rate of accumulation of dry matter in grains derived from assimilates during photosynthesis besides being influenced by genetic factors. Asimilat in sorghum plants in the form of nutrient content including ash content, protein, crude fat, crude fiber and carbohydrates (Salisbury and Cleon 1986). The levels of ash, protein, crude fat, crude fiber and carbohydrates contained in nine genotypes were varied (Table 9). When compared with nutritional range of sorghum (Andriani and Isnaini 2013), the ash and crude fiber content was relatively high, the protein varies (the highest is Sb.Spg 1 genotype of $15.30 \%$ and the lowest Sb.Tag 1 genotype of $8.97 \%$ ), medium crude fat (ranged from 2.58-4.33\%) while carbohydrates were below the minimum limit (ranging from $61.27-69.47 \%$ ).

In conclusion, all quantitative characters, including morphological characters (plant height, number of leaves, stem diameter, panicle length, number of grains panicle ${ }^{-1}$, grain weight panicle ${ }^{-1}$, weight of 100 grains) and agronomic characters (number of tillers, production hectare $^{-1}$, flowering age, flowering to harvest age and harvest age) indicate diversity. Qualitative characters showed diversity in young leaf color, old leaf color, leaf bone color, shape and density panicle, grain covering (glume length), glume color and grain color. Diversity was also shown in physiological characters with the highest protein potential $(15.30 \%)$ achieved by the Sb.Spg 1 genotype, the highest crude fat $(4.33 \%)$ achieved by the Sb.Tbn genotype, the highest carbohydrate (69.47\%) achieved by Sb.Lmg 1 genotype and the highest crude fiber (7.14\%) were achieved by the Sb.Tag 2 genotype. Based on all characters used, there are five genotypes that can be recommended for breeding programs, namely $\mathrm{Sb}$. Lmg 1, Sb Tbn., Sb.Spg 2. Sb.Tag 1 and Sb.Tag 2. This can be proved by the morphological character, genotype $\mathrm{Sb}$. Lmg1, Sb Tbn, Sb.Spg 2, Sb. Tag1 and Sb. Tag2 that has a high value; according to agronomic characters, genotype Sb. Tbn, Sb.Tag 1 and Sb. Tag 2 recorded highest production acres-1 with harvest age of short and medium, based on physiological characteristics, genotypes Sb.Lmg 1 and Sb.Spg 2 have the highest carbohydrate and protein content high.

\section{ACKNOWLEDGEMENTS}

This research was supported financially by the Merdeka Pasuruan College Foundation. We appreciate the technical assistance of the Agrotechnology Laboratory, Merdeka Pasuruan University, Indonesia and the Nutrition Laboratory of the University of Muhammadiyah Malang, Indonesia.

\section{REFERENCES}

Aminon ID, Loko LY, Adjatin A, Ewédjè EEBK, Dansi A, Rakshit S, Cissé N, Patil JV, Agbangla C, Sanni A, Akoègninou A, Akpagana K.
2015. Genetic divergence in Northern Benin sorghum (Sorghum bicolor L. Moench) landraces as revealed by agro morphological traits and selection of candidate genotypes. Sci World J 10: 1-10.

Andriani A, Isnaini M. 2013. Morphology and growth phases of sorghum. In: Sumarno, Damardjati DS, Syam M, Hermanto (eds). Sorghum: Technology Innovation and Development. IAARD Press, Jakarta. [Indonesian]

Balakrishna D, Bhat BV. 2015. Biology of Sorghum bicolor (Sorghum). Ministry of Environment, Forest and Climate Change and Indian Institute of Millets Research, New Delhi.

du Plessis J. 2008. Sorghum Production. Department Agriculture, Republic of South Africa, Pretoria.

Elvira SD, Yusuf M, Maiyuslina. 2015. Agronomic characteristics of several sorghum varieties on marginal land in North Aceh. J Agrium 12 (1): 1-4.

Gerik T, Bean B, Vanderlip R. 2003. Sorghum Growth and Development. Texas Cooperative Extension, Texas.

Hasidah, Mukarlina, Rousdy DW. 2017. Chlorophyll, carotenoid and anthocyanin content of caladium leaves. Protobiont J 6 (2) : 29 - 37.

House LR. 1985. A guide to Sorghum Breeding. International Crops Research Institute for the Semi-Arid Tropics. ICRISAT Patancheru, Andhra Pradesh, India.

IBPGR, ICRISAT. 1993. Descriptors for sorghum [Sorghum bicolor (L.) Moench]. International Board for Plant Genetic Resources, Rome.

ICRISAT. 2004. Sorghum, a Crops of Substance. Consultative Group on International Agricultural Research. Hyderabad, India.

Kimber CT, Dahlberg JA, Kresovich S. 2013. The gene pool of Sorghum bicolor and its improvement. In: Paterson AH (ed). Genomics of the Saccharinae, Plant genetics and genomics: Crops and Models. Springer Science+Business Media, New York.

Kumar AA, Hari Sharma HC, Sarma R, Blummel M, Reddy PS, Reddy BVS. 2015. Phenotyping in Sorghum [Sorghum bicolor (L.) Moench]. In: Panguluri SK, Kumar AA (eds.). Phenotyping for Plant Breeding: Applications of Phenotyping Methods for Crop Improvement. Springer Science+Business Media, New York.

Kusumawati A, Putri NE, Suliansyah I. 2003. Characterization and evaluation of several sorghum genotypes (Sorghum bicolor L) in Sukarami, Solok District. J Agrotek, 4 (1): 7-12.

Lamptey S, Nyarko G, Falon A, Yeboah S. 2014. Assessing the performance of sorghum varieties in the Guinea Savanna Zone of Ghana. Asian J Agric Food Sci 2 (1): 64-72.

Luna P, Widowati S. 2014. The potential and development of sorghum in East Java in the efforts of the national food diversification movement. Postharvest Agricultural Research and Development Center. Bogor.

Mejia D, Lewis B. 1999. Sorghum: Post-harvest Operations. Post-harvest Compendium. Food and Agriculture Organization of the United Nations, Rome.

Mofokeng MA, Watson G, Shimelis H, Tongoona P. 2012. Comparison between random amplified polymorphic DNA (RAPD) and simple sequence repeat (SSR) markers with high-resolution melt analyses in genetic variation analysis among selected sorghum genotypes. African J Biotechnol 11 (102): 16697-16707.

Salisbury FB, Ross CW. 1992. Plant Physiology. Wasdword Publishing Co. A division of Wasdword Inc.

Suarni, Firmansyah IU. 2013. Structure, nutrition composition and sorghum processing technology. In: Sumarno, et al. (eds). Sorghum: Technology Innovation and Development. IAARD Press, Jakarta.

Subagio H, Suryawati. 2013. Producing areas and variety of sorghum use in Indonesia. In: Sumarno, Damardjati DS, Syam M, Hermanto (eds). Sorghum: Technology Innovation and Development. IAARD Press, Jakarta. [Indonesian]

Subagio H, Aqil M. 2014. Assembly and development of sorghum superior varieties. Food Crop Sci and Tech 9 (1): 39-50.

Sumarno, Zuraida N. 2008. Management of plant germplasm integrated with breeding programs. Germplasm Bull 14 (2): 57-67.

Susilowati SH, Saliem HP. 2013. Sorghum trade in world and Asian markets and prospects for development in Indonesia. In: Sumarno, Damardjati DS, Syam M, Hermanto (eds). Sorghum: Technology Innovation and Development. IAARD Press, Jakarta. [Indonesian]

Tabri F, Zubachtirodin. 2004. Sorghum plant cultivation. In: Sumarno, et al. (eds). Sorghum: Technology Innovation and Development. IAARD Press, Jakarta.

Talanca AH, Andriani NN. 2013. Development of sorghum variety assembly in Indonesia. In: Sumarno, Damardjati DS, Syam M, Hermanto (eds). Sorghum: Technology Innovation and Development. IAARD Press, Jakarta. [Indonesian] 
Taiz L, Zeiger E. 2002. Plant Physiology. Sinauer Associates, Sunderland. UPOV. 2015. Sorghum. In: Guidelines for The Conduct Test for Distinctness, Uniformity, and Stability. International Union for the Protection of New Varieties of Plants, Geneva.

Munsell AH. 2012. Munsell Colour Charts for Plant Tissues. Munsell Color, Grand Rapids, MI, USA
Yoseph T, Sorsa Z. 2014. Evaluation of sorghum (Sorghum bicolor (L.) Moench) varieties, for yield and yield components at Kako, Southern Ethiopia. J Plant Sci 2014; 2 (4): 129-133.

Zubair A. 2016. Sorghum: Multi-benefit Plant. Unpad Press, Bandung. [Indonesian] 